\section{METALO DETEKTORIAI LIETUVOS ARCHEOLOGIJOJE: PO 20 METŲ}

Šiuolaikiniuose archeologiniuose tyrimuose taikoma daug ir ịvairų inovacijų: tiek žinomų nuo seno, tiek naujų ir dar bandomų. Kartais net sunku pasakyti, kuriai grupei priklauso metalo detektorius. Nurodoma, kad 1874 m. prancūzų inžinierius Gustave'as Pierre'as Trouvé (1839-1902) sukonstravo pirmąji detektorių kulkoms žmogaus kūne aptikti' ${ }^{1} 1881 \mathrm{~m}$. ji patobulino telefono išradejjas škotas Alexanderis Grahamas Bellas (1847-1922), o nešiojamąji detektorių 1925 m. pirmasis užpatentavęs Gerhardas Fischaras $1931 \mathrm{~m}$. juo pradejo prekiauti ${ }^{2}$.

Archeologiniuose kasinejjimuose turèjo būti seniai ir visuotinai taikomas, nes jo nauda akivaizdi. Tinkamas metalo detektorių naudojimas leidžia surinkti kone 100 procentų metalinių dirbinių iš tiriamos vietos. Apie tai, remdamasis daugiau Lietuvos archeologijos pavyzdžiais ir savo patirtimi, anksčiau rašiau ne kartą (Zabiela, 1996; 1998; 2004; 2012). Nuo to laiko praejjo pora dešimtmečių, tad kokių pokyčių ìvyko šioje srityje, kokios problemos išspręstos ir su kokiais iššūkiais susidurta? Remdamasis Lietuvos archeologų sukaupta patirtimi, tai trumpai apžvelgsiu.

Lietuvoje metalo ieškikliai neuždrausti. Jie laisvai ịvežami ị šalị ir pardavinèjami. Pagrindinis jų tiekejjas šiuo metu yra UAB „Tesora“, iš kurios ieškiklius yra pirkę ir nemažai Lietuvos archeologų. Galima įsigyti pačių ịvairiausių jų modifikacijų, nelygu kokių tikslų siekia jų naudotojai.

Archeologams visai nebūtina vaikytis naujausiųjų modelių, nes pagrindinis jų panaudojimo kasinejjimuose tikslas yra lokalizuoti ir surinkti visus metalinius dirbinius, tad paieškos gylis ar dirbinio rūšis - tai dažnai kaip privalumus pabrèžia ieškiklių gamintojai - yra nesvarbu. Kasinëjimuose svarbūs kiti du ieškiklių parametrai: jautrumas (dalis archeologinio metalo būna labai smulkūs ir sunykę) bei atsparumas nemetalinès aplinkos trikdžiams (turinčioms metalų priemaišų, perdegusioms ar kitokius trikdžius keliančioms uolienoms, griuvenoms ar panašiai). Tačiau galiausiai efektyvus metalo ieškiklio panaudojimas priklauso nuo operatoriaus patirties. Iki kraštutinumo sumažejusiuose archeologiniuose žvalgymuose (naujų archeologijos objektų ieškant klasikine jų forma, o ne vykdant darbus paviršiniuose ar suardytuose gruntuose) svarbi diskriminacinè funkcija, tačiau ją šiandien turi kone kiekvienas metalo ieškiklis, tad ir čia vèl viskas remiasi operatoriaus patirtimi. Pastarajai sukaupti jau buvo pakankamai laiko, nes kai kurie archeologai ieškiklius naudoja jau ketvirtị amžiaus.

Juridinis metalo detektorių naudojimo pagrindas (jų naudojimą reglamentuojantys ịstatymai) menkai apibrèžtas. $2011 \mathrm{~m}$. rugpjūčio $16 \mathrm{~d}$. priimtas Paveldo tvarkybos reglamentas PTR 2.13.01:2011 „Archeologinio paveldo tvarkyba“ metalo ieškiklius priskiria prie žvalgymams naudojamos įrangos (10 straipsnio sąvoka), draudžia juos naudoti ieškant kultūros objektų archeologinio paveldo objektuose, jų teritorijose ir apsaugos zonose neturint Kultūros paveldo departamento leidimo (13 straipsnis - ta pati nuostata yra ir nekilnojamojo kultūros paveldo apsaugos ístatymo 17.1 straipsnyje) ir, kalbant apie tyrimų metodiką, ịpareigoja juos naudoti tiriant metalų laikotarpio ir vèlesnių epochų archeologinio paveldo objektus (19.8 straipsnis).

Pagal nutylejimą visa kita veikla naudojant metalo ieškiklius yra galima, tik čia 2010 m. priimta

\footnotetext{
${ }^{1}$ https:/en.wikipedia.org/wiki/Gustave_Trouv\%C3\%A9 [žiūrèta 201907 18].

${ }^{2}$ https://www.thoughtco.com/history-of-the-metal-detector-1992303 [žiūrèta 201907 18].
} 
nuo 1996 m. galiojančio kilnojamųjų kultūros vertybių apsaugos ịstatymo 12.4 straipsnio pataisa ịpareigoja bet kur ieškant kultūrinę vertę turinčių daiktų turèti atestatą. Tokio atestato išdavimo tvarkos nèra, o abiejų minètų i̇statymų nuostatos dèl metalo detektorių iš dalies prieštarauja viena kitai (dalinis ribojimas prieš visuotinị). Esant nenusistovejjusiam ir gana jautriam požiūriui ị metalo detektorių naudojimo ieškant kultūros paveldo objektų problemą bei Lietuvoje privačių asmenų turint mažiausiai kelis tūkstančius detektorių (jie perkami naudoti) toks teisinis nihilizmas yra rimta kliūtis civilizuotai sprendžiant visuomenès (ieškotojai yra jos dalis) santykius su paveldu.

Per pastaruosius porą dešimtmečių Lietuvos archeologų požiūris ị metalo detektorius pakito. Nors tyrimams juos pradèjo naudoti dar ne kiekvienas (čia svarbiau ne naudojimo faktas, o jo efektyvumas), tačiau iš esmès nebeliko neigiančių metalo detektorių naudą. Detektorius pamažu ịsitvirtina kaip būtinas prietaisas, ir tai pasakytina tiek apie kasinejjimus, tiek apie žvalgymus. Tačiau archeologų bendruomenę geriausiu atveju sudaro mažiau nei 300 narių (2019 m. Lietuvos archeologijos draugijoje buvo 232 nariai $^{3}$ ), o metalo detektorių naudotojų yra mažiausiai keli tūkstančiai, tad būtent pastarųjų santykis su kultūros paveldo objektais ir yra lemiamas veiksnys formuojant vienokią ar kitokią nuomonę ir veiksmų praktiką.

Ilgą laiką metalo ieškiklių naudotojai (toks apibendrinantis pavadinimas šiuo atveju bene geriausiai tinka, nes pastarųju neskirsto pagal interesus) buvo labai ịvairialypiai ir neorganizuoti. Mus dominančiame santykyje su kultūros paveldu kažkokių žurnalistų lengva ranka jie buvo įvardyti ,juodaisiais archeologais“, nors čia kokia nors archeologija, tuo labiau su „rasistiniu“ atspalviu ir nekvepia ${ }^{4}$. Šis terminas daugiau vartojamas Rusijoje ir buvusiose socialistinèse šalyse bei susijęs su II pasaulinio karo laikų kapų plèšikais, dirbančiais rinkai ${ }^{5}$. Lietuvoje paveldo plèšikus, matyt, tikslingiausia vadinti brakonieriais, nors šis žodis iki šiol turi tik nelegalių veiksmų gyvūnų atžvilgiu aspektą. Brakonieriaus konotacija visuomenejje yra aiškiai neigiama ir nekelianti kontroversijų, tad taip ịvardyti nelegalius kasinètojus, manau, galima. Galiausiai brakonieriaus terminas tyliai suponuoja kažkokius kitus veiksmus, kuriuos atlikęs pilietis juo nelaikomas. Tai būtų netgi savotiškas paskatinimas valdžiai tokius veiksmus padaryti.

Nelegalių kasinètojų problemą labai išryškino Apuolès kapinyno (Skuodo r.) byla. 2009 m. birželị buvo sulaikyti du vilniečiai, su metalo detektoriais plèšę gerai žinomą valstybės saugomą kapinyną. Po 4 metus trukusio tyrimo už ši nusikaltimą $2013 \mathrm{~m}$. jie buvo nuteisti laisvès atėmimo bausmèmis - 3,5 ir 4 metams $^{6}$. Ši byla tarsi nubrèžè ribą, kuria valstybė parodè, kad saugomų archeologijos paveldo objektų plèšimo ji netoleruos. Kadangi svarbus plèšimo instrumentas buvo metalo detektoriai, kai kam pasirodè, kad netoleruotini ir jie. Tačiau ši tendencija, laimei, pasekmių nesulaukè.

Archeologų bendruomenès santykį su metalo detektoriais pradejo keisti $2014 \mathrm{~m}$. susikūrusi asociacija „Metalo ieškiklių naudotojų klubas“ (MINK), pradejusi bendradarbiauti su Lietuvos archeologijos

\footnotetext{
${ }^{3}$ http://lad.lt/lietuvos-archeologijos-draugija/ [žiūrèta 201907 19].

${ }^{4}$ JAV nuo 2011 m. egzistuoja Juodųjų archeologų draugija (Society of black archaeologists), užsiimanti įvairiomis Afrikos archeologijos problemomis - https://www.societyofblackarchaeologists.com/ [žiūrèta 201907 19].

5 https://traffickingculture.org/encyclopedia/terminology/black-archaeologists-tchorniye-arkheologi-\%D1\%87\%D1\%91\%D 1\%80\%D0\%BD\%D1\%8B\%D0\%B5-\%D0\%B0\%D1\%80\%D1\%85\%D0\%B5\%D0\%BE\%D0\%BB\%D0\%BE\%D0\%B3\%D0\%B8/ [žiūrèta 201907 19].

${ }^{6}$ https://www.15min.lt/naujiena/aktualu/nusikaltimaiirnelaimes/vilniuje-nuteisti-neteisetai-kapinyna-salia-apuoles-kasinejedu-juodieji-archeologai-jie-tures-atlyginti-puses-milijono-litu-zala-59-338712 [žiūrèta 201907 19].
} 
draugija ir atskirais tyrimus vykdančiais archeologais. Jau 2014 m. rudenị MINK talkino Levizarų (Utenos r.) (Sadauskas, 2015) ir Glaudžių (Plungès r.) (Račas, 2015) laidojimo vietų tyrimuose. Tik MINK dèka Lietuvoje buvo galima pradèti vystyti tokią naujų archeologinių objektų, kaip mūšių laukai, tyrimus (Saulès mūšio vietos paieškos 2015 metais - Baranauskas, Zabiela, 2016). Sukaupta patirtis buvo apibendrinta. Iki $2019 \mathrm{~m}$. vasaros vidurio mažiausiai 2 MINK nariai bent po 3 valandas yra dirbę 96 archeologiniuose tyrimuose $\mathrm{f}^{7} .2017 \mathrm{~m}$. gruodžio $8 \mathrm{~d}$. su Lietuvos archeologijos draugija Vilniaus universitete ivvyko seminaras „Metalo ieškikliai Lietuvos archeologijoje“. 2018 m. MINK tapo Europinès metalo detekcijos tarybos (ECMD) nare. MINK bendradarbiavimo su archeologais sukaupta patirtis šiandien leidžia kalbėti bent apie porą archeologinių radinių interpretavimo aspektų, kuriuos nagrinėti anksčiau nebuvo įmanoma arba labai trūko duomenų.

Pirmasis jų yra tikras metalinių radinių kiekis tiriamoje vietoje. Jau seniai buvo pastebèta, kad, nenaudojant metalo detektorių, nerandama apie pusès visų metalinių radinių - daugiausia smulkių. Geriausi pavyzdžiai - iš vienos svarbiausių radinių grupių monetų. Pastarąsias archeologai visais laikais ir visuose objektuose stengèsi aptikti, nes tai yra labai svarbus, dažnai ir vienintelis sluoksnio, komplekso ar net objekto datavimo būdas. Lygiai taip pat monetos yra svarbus ieškotojų radinys, tik dažnai kitu numizmatiniu - aspektu, o metalo detektoriai šiandien konstruojami taip, kad geriausiai skirtų būtent monetas ar $\mathfrak{i}$ jas panašius daiktus.

Tad turime dvi gerai palyginamas duomenų bazes: monetas, surastas be detektorių ir su detektoriais. Norint gauti objektyvius rezultatus, aišku, reikia tarpusavyje lyginti ir panašius objektus, nes monetų paplitimas ir pametimas buvo labai skirtingi. Ivertinti metalo detektorių efektyvumui pasirinkta pora objektų Lietuvos vietose, kur iš pradžių buvo tyrinejjama nenaudojant detektorių, vèliau - naudojant.

Vilniaus Žemutinès pilies teritorijoje tyrimai iki $1987 \mathrm{~m}$. vykdyti be metalo detektorių ir nuo $1900 \mathrm{~m}$. rasta vos daugiau kaip šimtas monetų. 1987 m. tyrimus atnaujinus ir pradejus naudoti detektorius per 20 metų jų surasta 5000 su viršum. Ir tai tikrasis monetų skaičius po 1987 m. tirtose vietose galèjo būti bent dvigubai didesnis, nes metalo detektorius iki $2000 \mathrm{~m}$. naudotas ne visuomet ir ne visur. Manoma, kad 1998-2000 m. rekonstruojant Katedros aikštę ir nenaudojant metalo detektoriaus buvo prarasta keli tūkstančiai monetų (Remecas, 2009, p. 115). Tas Vilniaus pilių atveju monetų, aptiktų be detektorių ir su detektoriais, santykis tiesiog neįtikètinas - 1: 100 .

Vilniaus periferijoje, Lukiškių aikštėje, 1992 ir 2004 m. atlikti nedidelių apimčių archeologiniai tyrimai monetų nepateike, o 2015-2017 m. atliekant aikštès rekonstrukcijos darbus ir naudojant metalo detektorius aptikta 450 (Širvydaitè, 2016, p. 369; Vaitkuvienè, Žemantauskaitè, Fediajevas, 2018, p. 463, 467). Dar šiek tiek monetų rasta 2017 m. aikštės prieigose dirbant kitiems tyrëjams (Kvizikevičius, Vutkin, 2017, p. 407). Taigi šie duomenys iš esmès patvirtina aukščiau nurodytus skaičius.

Platesnis metalo detektorių naudojimas, ypač žvalgymams, leido atkreipti dèmesị ị dar vieną problemą, kuriai spręsti iki tol neturèta instrumentų. Tai pavieniai radiniai. Visais laikais žmonès kažką pamesdavo, ir tai nutikdavo ne tik gyvenamosiose vietose, kur tokie dirbiniai yra sudedamoji kultūrinio sluoksnio dalis, bet ir visiškai atsitiktinèse, neapgyventose vietose. Archeologai tokių vietų netyrinejja, tad žmonių pagamintų dirbinių (labiausiai pastebimi akmeniniai kirvukai) randama atsitiktinai darant kitokius darbus. Tuos kirvukus jau išmokome vertinti kaip pavienius radinius (kartais gal ir be reikalo, ypač jeigu jų toje vietoje rasta ne vienas), o gražesni metaliniai dirbiniai neretai priskiriami

${ }^{7} 20190727$ Andriaus Čepukèno (MINK) informacija. 


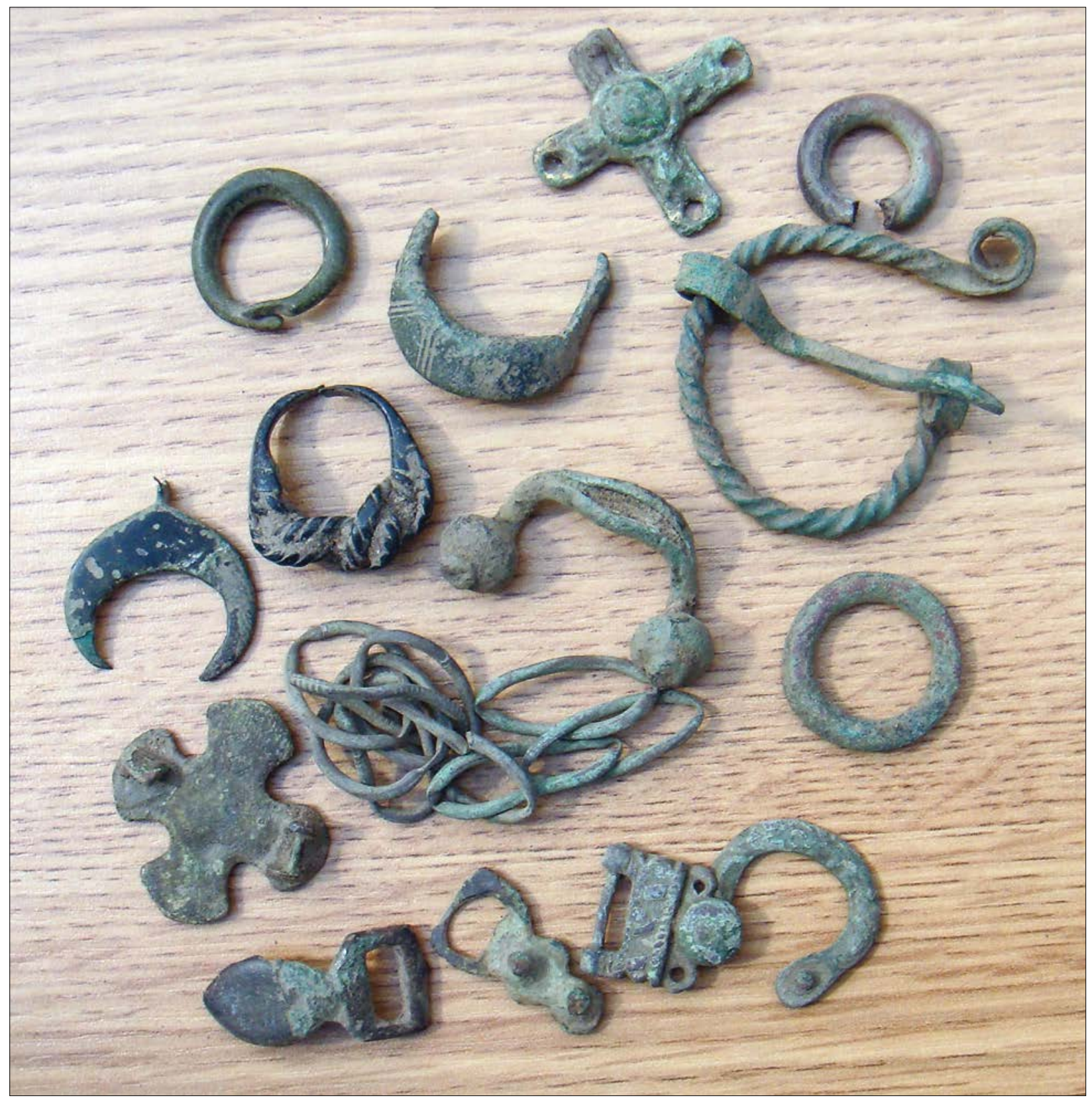

Ieškotojų sąskrydžio metu Bukonyse (Jonavos r.) 2019 m. surinkti pavieniai radiniai. E. Petukausko nuotr.

prie dar nežinomų kapinynų ar gyvenviečių indikatorių ir praeityje yra ne kartą patarnavę tokių vietų ịpaveldinimui, ypač jeigu rasti būdingame reljefe (kalvelèse ar lygiose vietose prie vandens). Ieškotojų patirtis bei archeologiniai žvalgymai parodè, kad pavieniai metaliniai dirbiniai, nesvarbu, kokia jų būklè, pirmiausia turètų būti vertinami kaip atsitiktiniai ir iš jų nedaromos platesnès išvados. Ateityje su metalo detektoriais reikètų patikrinti ir kai kurias dabar saugomas vietas, kuriose yra rasta po metalinį radinị. Nepaisant tikrai ịspūdingų radinių ir tyrimų, atliktų naudojant metalo detektorius, ypač per pastarąji dešimtmetị, juridinis ieškotojų statusas išlieka vadinamojoje pilkojoje neapibrěžtumo zonoje. Apie 
85 procentai Lietuvos teritorijos žemès kasimo aspektu nèra niekaip saugoma, ir būtent šios teritorijos yra ieškotojų darbo laukas. Metalo detektorius nenurodo dirbinio pagaminimo laiko, tad, juo ieškant vakar pamesto žiedo, galima rasti ir tūkstančio metų senumo žiedą, kuris jau yra archeologijos vertybè. Jos kelias ị mokslininko kabinetą ir muziejų saugyklas painus.

Dabar galiojančiuose ìstatymuose archeologinių radinių sąvoka neapibrèžta. Juridiškai apibūdinti tik ypatieji radiniai (baigiant XVIII amžiumi datuojami archeologiniai radiniai, teikiantys esminę informaciją apie objekto pobūdị, chronologiją ir kultūrinę vertę ${ }^{8}$ ), sudarantys tik dalị visų archeologinių radinių. Pastarieji tik įvardyti kultūrinès vertès daiktais, o vertė apibrěžiama kaip kilnojamojo daikto ar jo dalies savybè, vertinga archeologiniu ar kitu požiūriu9. Sukurta tautologija (sąvoka apibrèžiama ta pačia sąvoka) - archeologiniai radiniai yra vertingi, nes jie archeologiniai.

Metalo detektorius teisètai gali naudoti tik mokslo tyrimų institucijos ir tyrèjai ${ }^{\mathbf{1 0}}$, kurie turi būti atestuoti $^{11}$, o atestatui gauti turi atitikti sąlygas ${ }^{12}$, dvi iš kurių (aukštasis mokslas ir darbo stažas) yra specifinès profesinès. Vadinasi, metalo detektoriai turètų būti išimtinai archeologų tyrèjų naudojamas instrumentas. Tačiau iš tikrųjų dèl ịvairių minètų priežasčių to irgi nèra. Dèl aiškios teisinès kolizijos metalo detektoriais aptinkami archeologiniai radiniai slepiami ir depasportizuojami - jie prarandami archeologijos mokslui, paveldo apsaugai ir nacionaliniam turtui.

Metalo detektoriai aštriai iškèlè archeologijos viršutinès ribos problemą. Pagal Paveldo tvarkybos reglamentą „Archeologinio paveldo tvarkyba“ tai yra
1800 m., tačiau ịvairaus metalo ypač daug randama Naujausiaisiais laikais (po 1800 m.). Būtent šio laikotarpio dirbiniai ir sudaro absoliučią metalo detektoriais aptinkamų radinių dalį. Be pačių ịvairiausių šiuolaikinių šiukšlių, dažnai fragmentuotų ir blogos būklès geležinių statybinių detalių, sprogmenų skeveldrų, pasitaiko ir kultūriniu ar istoriniu požiūriu vertingų dirbinių, ypač monetų. Palyginti gausu ir militarijos: kulkų, šovinių tūtelių ir kt. Visa tai pastaruoju metu didejančiu srautu plūsta ị muziejus ir užpildo ataskaitų puslapius, nors kokios nors esminès informacijos apie praeitị dažniausiai nesuteikia.

Dar viena neišspręsta, su metalo detektoriais susijusi mokslinè ir paveldosauginè problema, yra radinių kiekio, reikalingo archeologiniam objektui identifikuoti, nustatymas. Žvalgant archeologinio metalo turtingus objektus, pvz., geležies amžiaus kapinynus, galima nesunkiai ir greitai surinkti ištisas tokių dirbinių kolekcijas, kurios vis viena bylos apie viena - čia yra (ar būta) to laiko kapinyno. Pavyzdys čia gali būti Suginčių (Akmenès r.) kapinynas, kuriame 2017 m. metalo detektoriais surinkta 123 archeologiniai dirbiniai iš suardytų V-VIII a. kapų (Petrauskas, 2018, p. 546). Lietuvos sąlygomis racionalus objektą indikuojančių nustatomos paskirties (ne neaiškių fragmentiškų) dirbinių skaičius neturètų viršyti 10-ies (tai vieno-dviejų suardytų kapų ¡kapès, istorinių laikų pastato vietos metalas arba kelių šimtų kvadratinių metrų geležies amžiaus gyvenvietės radiniai). Didesnio skaičiaus archeologinių vertybių išrinkimas iš objekto yra jau atskirų tyrimų reikalas.

Archeologų darbui su metalo detektoriais reikia skirti gana daug dèmesio. Vien tik pasižadejjimo tyrimų projekte, kad bus naudojamas metalo

\footnotetext{
${ }^{8}$ Paveldo tvarkybos reglamento „Archeologinio paveldo tvarkyba“ 10 straipsnis.

${ }^{9}$ Kilnojamųjų kultūros vertybių apsaugos įstatymo 2:8 straipsnis.

${ }^{10}$ Nekilnojamojo kultūros paveldo apsaugos įstatymo 18:2 straipsnis.

${ }^{11}$ Kilnojamųjų kultūros vertybių apsaugos įstatymo 12:4 straipsnis.

${ }^{12}$ Nekilnojamojo kultūros paveldo apsaugos įstatymo $23^{1}: 5$ straipsnis.
} 
detektorius, neužtenka. Šiuo atžvilgiu labai akivaizdūs dviejų gretimų Kauno senamiesčio sklypų tyrimai, vykę beveik vienu laiku. 2015 m. Šv. Gertrūdos gatvejje 51 ištyrus $3084,5 \mathrm{~m}^{2}$ plotą aptikti 236 ypatieji radiniai (Mačiulis, Simanavičiūtè, 2016, p. 271, 276). 2016 m. Šv. Gertrūdos gatvèje 51A $1200 \mathrm{~m}^{2}$ plote rastos 303 monetos (Girlevičius, Fediajevas, 2017, p. 284). Kokią dalị tarp jų užėmė monetos, neaiš$\mathrm{ku}$, nes tyrimų ataskaita dar neparašyta. Skaičiuojant pagal ištirtą plotą $2015 \mathrm{~m}$. viena moneta buvo rasta $13,07 \mathrm{~m}^{2}$ (jeigu laikytume, kad i ypačiųjų radinių sąrašą buvo įtrauktos vien tik monetos, o tai yra neįmanoma), $2016-3,96 \mathrm{~m}^{2}$, taigi aptiktų monetų santykis yra $1: 3,3$. Metalo detektorius $2015 \mathrm{~m}$. tyrimams buvo naudojamas, matyt, tik epizodiškai ir archeologų ar darbininkų. $2016 \mathrm{~m}$. tyrimuose juo dirbo gerai pasirengę MINK nariai. Išvada galima tik viena: archeologiniuose kasinejjimuose metalo detektoriais turi dirbti atskiri, juos gerai ịvaldę žmonès.

Neišspręstas ir Naujausiųjų laikų numizmatikos ir archeologijos santykis. XIX-XX a. monetos kaldintos milžiniškais tiražais, gerai pažįstamos iš kolekcijose (įskaitant muziejų) esančių puikiai išlikusių pavyzdžių, gausių rašytinių šaltinių. Archeologijoje jos irgi tik pagalbinė datavimo priemonè, nes šio laikotarpio kasinejjimai vykdomi jau konkrečių istorinių šaltinių pagrindu ir juos gali tik patikslinti, tačiau paprastai ne chronologiją. Tad šio laikotarpio monetų radimo, jų registravimo ir saugojimo (ar ne) reikalus turi spręsti numizmatai.

Kaip bebūtų paradoksalu, šiuolaikinès žemès ūkio technologijos turi skatinti spartesnę ieškotojų veiklą, nes po dešimtmečio - poros dešimtmečių viršutinėje dirbamųjų laukų dirvožemio dalyje nebeliks daugelio čia dar esančių archeologinių dirbinių. Pirmiausia tai susiję su žemès frezavimo technologijų plitimu, kai gruntas yra tiesiog sumalamas, todèl žūsta ir ten esantys artefaktai. Aišku, pirmiausia nukentès trapiausi ir didesni dirbiniai, tačiau ypač dèl metalų korozijos smulkesnieji tokiomis sąlygomis irgi ilgai neišsilaikys.
Du pastaruosius dešimtmečius archeologams naudojant metalo detektorius dalis problemų buvo išspręsta, bet atsirado naujų. Dalis jų yra archeologų bendruomenès sutarimo reikalas, tad jeigu jos nesprendžiamos, tai reikia kaltinti tik save pačius, bet viešo metalo detektorių naudojimo nesaugomose teritorijose reikalų sutvarkymas yra valstybinès svarbos reikalas. Kaip jis bus išspręstas, priklauso nuo teisinès paveldosaugos sistemos brandos. Šiandien atrodo, kad jos dar reikès gerokai palaukti.

\section{LITERATŪROS SĄRAŠAS}

Baranauskas, T., Zabiela, G., 2016. Saulès mūšio pédsaku paieškos. Vilnius: Lietuvos archeologijos draugija.

Girlevičius, L., Fediajevas, O., 2017. Šv. Gertrūdos gatvè 51A. Archeologiniai tyrinëjimai Lietuvoje 2016 metais, 275-286.

Kvizikevičius, L., Vutkin, P., 2018. Lukiškių aikštè bei gatvè Vilniuje. Archeologiniai tyrinejimai Lietuvoje 2017 metais, 406-407.

Mačiulis, M., Simanavičiūtè, E., 2016. Šv. Gertrūdos gatvè 51. Archeologiniai tyrinèjimai Lietuvoje 2015 metais, 271-276.

Petrauskas, G., 2018. Naujų paminklų paieškos Akmenès rajone. Archeologiniai tyrinèjimai Lietuvoje 2017 metais, 541-549.

Račas, J., 2015. Glaudžių kapinynas. Archeologiniai tyrinejimai Lietuvoje 2014 metais, 158-161.

Remecas, E., 2009. Monetų kompleksai, rasti tiriant Vilniaus Žemutinès pilies teritoriją. Lietuvos pilys, 5, 116-129.

Sadauskas, I., 2015. Levizarų pilkapio vieta. Archeologiniai tyrinejimai Lietuvoje 2014 metais, 129-131.

Širvydaitè, S., 2016. Lukiškių aikštès žvalgomieji tyrimai. Archeologiniai tyrinèjimai Lietuvoje 2015 metais, 367-371.

Vaitkuvienè, A., Žemantauskaitè, M., Fediajevas, O., 2018. Lukiškių aikštės tyrimai 2016 ir 2017 m. 
Archeologiniai tyrinejimai Lietuvoje 2017 metais, 459-470.

Zabiela, G., 1996. Metalo detektorių naudojimas archeologiniuose tyrinejimuose. Archeologiniai tyrinejimai Lietuvoje 1994 ir 1995 metais, 388-390.

Zabiela, G., 1998. Application of alternative methods in Lithuania field archaeology (up to 1996). Archaeologia Baltica, 3, 147-153.
Zabiela, G., 2004. Metalo detektoriai archeologiniuose kasinejjimuose: neịsisąmoninta būtinybè. Lietuvos archeologija, 26, 167-172.

Zabiela, G., 2012. Metal detectors. In: Zabiela, G., Baubonis, Z., Marcinkevičiūtè, E., eds. Archaeological investigations in independent Lithuania 19902010. Vilnius: Lietuvos archeologijos draugija, 420-422.

Gintautas ZABIELA

Klaipeddos universitetas Baltijos regiono istorijos ir archeologijos institutas gzabiela@gmail.com 